\title{
AVAilability Without ACCESS? \\ Globalization ANd Socio-Political Cleavages in EMERging ECONOMies
}

\author{
John Gledhill, University of Oxford \\ Richard Dolan, University of Oxford \\ Jeremy Snyder, Simon Fraser University
}

\begin{abstract}
Scholars argue that globalization is reconfiguring socio-political cleavages. No longer do class divisions dominate. Rather, the argument goes, societies are increasingly divided between 'cosmopolitans' (who welcome globalization) and 'communitarians' (who do not). While that may be the case, studies generally consider the impact of globalization on cleavages in advanced, rather than emerging, economies. Here, we address the latter context. By exploring the impact of liberalized healthcare and education on societal structures, we argue that globalization is encouraging social stratification that could underwrite the development of a cosmopolitan/communitarian cleavage in emerging economies. Specifically, we argue that an expansion of trade into new markets is increasing the availability of goods, services, and ideas, but the high cost of new products means that access is often restricted to local elites. Thus, while elites are connecting to global networks, non-elites are increasingly disconnected -- which is an arrangement that could foster a cosmopolitan/communitarian cleavage.
\end{abstract}

Authors' biographies: John Gledhill is Associate Professor of Global Governance in the Department of International Development, University of Oxford. Richard Dolan is a DPhil candidate in the Department of International Development at the University of Oxford. Jeremy Snyder is Associate Professor in the Faculty of Health Sciences, Simon Fraser University.

Acknowledgements: We thank Michael Bloomfield, Jane Knight, Ivan Manokha, and anonymous reviewers for their helpful comments on earlier drafts of this study. Any unintended errors, omissions, or misrepresentations are, of course, our own. 


\section{AVAILABILITY WITHOUT ACCESS? \\ Globalization and Socio-Political Cleavages in EMERging ECONOMIES}

The recent rise of populism in the United Kingdom (UK), United States (US), and beyond has triggered claims of a fundamental shift in the nature of political cleavages and competition, globally -- away from competition between traditional class-based groups, toward a political contest that pits 'cosmopolitan' winners of globalization against 'communitarian' losers thereof (Gonzalez-Vicente \& Carroll 2017; Gusterson 2017; Hobolt 2016; Rodrik 2017; Schmidt 2017). While qualitative and quantitative evidence has been corralled in support of this claim, existing accounts have generally focused on the impact of globalization on social divisions and political competition in regions that play host to advanced economies. This is understandable, perhaps, because these regions witnessed some of the biggest political earthquakes of 2016, including the Brexit referendum in the UK, the election of Donald Trump in the US, and the (re-)emergence of populist parties in Australia and Europe. Advanced economies are also most deeply entwined in networks of global trade in goods and services, and so we would expect the socio-political impact of globalization to be felt most strongly in these countries. Even if that is the case, however, it is also possible that processes of globalization are laying structural foundations for a reconfiguration of socio-political cleavages in 'emerging economies' -- states (outside 'the Global North') whose rapid growth over recent decades has been driven, in part, by increased integration into global networks of goods, services, and knowledge. Until now, however, academics and popular writers alike have given little consideration to this possibility.

Given that oversight, we investigate whether global processes of liberalization and privatization are (re)shaping structural inequalities in emerging economies, in a way that could underwrite the development of a cosmopolitan/communitarian cleavage in those countries. Based on a preliminary investigation of the societal impact of globalization in two sectors -healthcare and education -- we find that this could indeed be the case. On one hand, we find that privatization and liberalization of these two sectors is facilitating an increase in the availability of globalized goods, services, and ideas in emerging economies. However, the relatively high cost of globalized resources means that access to the newly-available services is often restricted to local elites and/or foreigners who have significant financial and political resources at their disposal. Over time, we argue, such stratified access to globalized resources within emerging economies is likely to see elites become increasingly connected to global 
products, ideas, and networks, while non-elites will remain connected to markets and ideas at the national level. This arrangement would provide a structural basis for the development of a cleavage between globalized elites and 'localized' non-elites. While this is a distinct possibility, we conclude by suggesting that such an outcome may be averted if private service providers, and the states that host such providers, offer subsidies and grant programs that can facilitate the access of all locals to globalized goods and services.

We develop our arguments in six steps. We first give a brief overview of existing understandings of the impact of globalization on socio-political cleavages (in advanced economies). We then introduce an analytic framework that can be used to assess the relationship between globalization and cleavages in emerging economies. After delimiting the scope of our empirical study, we sketch how a globalization of healthcare and education, respectively, is shaping the availability of, and access to, those services in emerging economies. We then conclude by reflecting on how social inequalities that are produced through differential access to globalized goods and services may shape socio-political cleavages in emerging economies, going forward.

\section{Globalization and Shifts in Socio-Political Cleavages: Existing Accounts}

There are well-known debates over the extent to which processes of globalization are reconfiguring social and political structures (see Held \& McGrew 2007), with so-called 'globalists' claiming that we are living in a period of deterritorialization that is fundamentally transforming markets and socio-political institutions (e.g. Scholte 2005; Dicken 2003), while 'sceptics' have rejected such claims as exaggerations of a less dramatic empirical reality (e.g. Hirst \& Thompson 2002; Krasner 2004). Among scholars who subscribe to the idea that globalization is transformative, however, there is growing recognition that liberalization of trade, finance, and labor, and an associated transnationalization of governance, are driving a shift in the nature of socio-political cleavages (Bornschier 2010; Kriesi et al. 2006) -- where that term is understood as "a deep and lasting division between groups based on some kind of conflict" (Bornschier 2009, 2). No longer do class cleavages divide societies according to the relationship of actors to the (national) means of production in (national) markets (see Goldthorpe 2002). Rather, the argument goes, societies are dividing along new cleavage lines, which split those who are engaged with (and benefit from) globalization from those who are relatively disengaged (and do not necessarily see benefits) from processes of globalization 
(Dancygier \& Walter 2015; Gruber 2015; Gonzalez-Vicente \& Carroll 2017; Gusterson 2017; Kriesi et al., 2006).

Scholars discuss (and describe) the divide between the 'winners' and 'losers' of globalization in various ways (see overview in Kriesi 2010, 683). Rodrik (2017), Pettifor (2017), and Toly (2017), for example, focus on the differential economic effects of globalization, highlighting a growing rift between actors and regions that profit from a liberalization of trade and those that seemingly bear the costs thereof. Crouch (2016), Hobolt (2016), and Gusterson (2017) explore issues of culture, identity, and immigration (alongside economics) and, in so doing, point to a growing split between advocates of multiculturalism and global integration, on one side, and supporters of nation-based identities and national communities, on the other. Kriesi et al. (2006) also consider economic and cultural dimensions of globalization when they distinguish between supporters of global 'integration' and defenders of 'demarcation', while Bornschier (2010) makes a similar distinction between 'libertarianuniversalist[s]' and 'traditionalist-communitarian[s]'. Zürn \& de Wilde (2016), Wheatley (2016), and others, meanwhile, discuss divisions between cosmopolitans, who say "yes to open borders, yes to global authorities, yes to individualism and yes to individual rights" (Zürn \& Wilde 2016, 293), and communitarians, who give primacy to the (national) community over the individual and, thus, tend to support social and economic protection within the bounds of nation-states. Since these latter categories -- cosmopolitans and communitarians -- provide a textured, but still parsimonious, way of describing emerging (and divided) social groups, we adopt them in discussion that follows.

Recent studies that have explored the cosmopolitan/communitarian split have offered important insights into the seismic political shifts that took place in a number of advanced democracies in 2016. Explanations of the outcome of Britain's referendum on exiting the European Union, for example, have identified a host of cosmopolitan/communitarian issues that split the British electorate, including: voters' levels of (dis)engagement with the globalized economy (Hobolt 2016; Pettifor 2017; Toly 2017); attitudes toward immigration (Matti \& Zhou 2017; Hobolt 2016; Schmidt 2017); and views on national sovereignty and supranational governance. Analyses of the 2016 US presidential election have also looked at how social divisions over the economic, social, and cultural impacts of globalization created space for populism to emerge in the US (Trubowitz 2016; Rodrik 2017). Donald Trump then stepped into that space by calling for 'Americanism, not globalism' (Saval 2017), while Bernie Sanders won wide support among Democrats by critiquing global neoliberalism and associated social 
inequalities (Schmidt 2017, 256). And, finally, the cosmopolitan/communitarian dynamic has been used to explain recent reconfigurations of party systems in continental Europe, where support for traditional parties has waned in favor of communitarian parties such as the Front National in France, or new -- and overtly cosmopolitan -- parties such as Emmanuel Macron's En Marche! movement (see Allègre 2017).

Studies that use the lenses of cosmopolitanism vs. communitarianism to explain major political shifts have certainly facilitated our understanding of recent political outcomes that few analysts predicted in advance. However, existing studies are arguably narrow in scope because they focus on the impact of globalization on cleavages in economically-advanced Western democracies, at the expense of exploring how globalization might shape social and political dynamics in other regions and regimes. This focus may reflect the fact that developed democracies have been most deeply enmeshed in processes of economic globalization over the past five decades and, as such, globalization has had the greatest social and political impact in those regions. The Western 'bias' may also have a methodological basis; survey and voting data are readily available in developed, Western democracies and so social and political trends can be relatively easily tracked in such countries. Either way, the Western focus means that, at present, our understanding of the (possible) impact of globalization on social structures and cleavages in emerging economies is limited. This is problematic, and not just for academic reasons; rather, if regions with emerging economies are now becoming fully integrated into the globalized economy, then it is important that we understand how such integration might shape cleavages going forward, so that steps can be taken to manage political divisions effectively.

To assess the potential impact of globalization on cleavages in emerging economies, two interrelated sets of questions need to be addressed. First, when and why are new sociopolitical cleavages likely to form? Second, might processes of globalization contribute to such a restructuring of cleavages in emerging economies? In the next section, we address the first question by combining insights from literatures that explore collective grievances, cleavages, and the political economy of development. We then use those insights as a basis for assessing whether the global privatization of public services that have traditionally been provided by states at the national level (healthcare and education, in particular) may contribute to a reconfiguration of socio-political cleavages in emerging economies. 


\section{Globalization, Deprivation, and Cleavages: A Framework for Analysis}

When and why might new socio-political cleavages emerge within a given society? The starting point for such a discussion should arguably be Lipset and Rokkan's (1967) classic study of cleavages and party structures in Europe. For our purposes, however, their work is of somewhat limited utility because it explores why cleavages and parties tend to persist over extended periods (Pierson 2000, 258), rather than why they occasionally change. While a number of recent studies have given consideration to the evolution of social cleavages (e.g. Bornschier 2010; Kriesi 2010, 1998; Kriesi et al. 2006; Wheatley 2016), those works have tended to focus on cleavages and party politics in Western Europe, in particular. Thus, while they offer broad theoretical insights into the question of cleavage change, the scope and application of those insights is partly limited to economically-advanced, democratic contexts where political parties are vehicles for the aggregation and articulation of interests. Since we are interested in cleavage change beyond Western, democratic contexts, we do not begin our analysis with the 'cleavages' literature. Instead, we take a theoretical step back and consider insights from literature that has investigated the origins of collective grievances, as a precursor to the development of societal divisions and political conflict. Specifically, we adopt and adapt the influential work of Ted Gurr.

Gurr's key early claim was that societies are liable to become divided and conflictual when one or more groups of actors perceive a gap between the opportunities and outcomes that they expect to enjoy and the outcomes that they capable of realizing, in reality (Gurr 1970). This can be the case if actors' expectations increase but their realization capability does not, or if their expectations remain constant but their capacity to realize those expectations wanes. Either way, Gurr argues, when a collection of individuals come to see a gap between their expected and actual life chances, they will share a common sense of injustice -- which he describes as a feeling of 'relative deprivation'. The term 'relative' is key because it suggests that absolute social/economic/political circumstances may matter less (for feelings of deprivation) than whether a set of actors believes that their opportunities are at least equal to opportunities that are enjoyed by other groups within their society -- since comparisons between groups partly shape expectations. If perceptions of deprivation indeed are 'relative' in this way, then the formation of groups around feelings of injustice should be seen as a process that not only binds, but also divides; after all, as individuals come together around a shared sense of deprivation, so too will they set themselves apart from -- and in opposition to -- other 
groups of actors who are seen to enjoy greater opportunities. Where that is indeed the case, there will be structural basis for the formation of a socio-political cleavage.

If the origins of cleavages are rooted in perceptions of relative inequality and injustice, then we need to identify the conditions under which such perceptions might arise. From a structural perspective, the answer lies in 'social realities' (see Mair 2012, 373) -- genuine inequalities that are determined by social, political, and/or economic arrangements that advantage some groups over others (e.g. class structures, racial or ethno-national hierarchies, gendered norms, and beyond). From a more pluralist perspective, however, the existence of objective structural inequalities cannot be sufficient for the development of a shared sense deprivation and associated societal divisions, simply because there are many more objective inequalities in the world than groups that perceive and organize around those inequalities. Recognizing the insufficiency of structural accounts, scholars of cleavages have pointed to the contributing roles of identity, ideology, organizations, and political agency in translating 'social realities' into collective grievances, which then constitute the pillars of a socio-political cleavage (Mair 2012; Kriesi 1998; Kriesi 2010; Zürn \& Wilde 2016, 283-84). While there is certainly logic to this synthetic approach, those who advocate for it also recognize that a focus on structural and agential causes of cleavages can create a highly complex causal matrix, which may be challenging to operationalize empirically. Thus, Kriesi $(1998,167)$ suggests a building block approach, in which the structural origins of inequalities are explored as a first step toward a broader investigation of the political origins of cleavages. Given the exploratory nature of this study, we take up this suggestion by assessing whether processes of globalization are (re)configuring structural inequalities within emerging economies.

\section{Availability, Access, and Cleavages in Emerging Economies}

To make such an assessment, we turn to works that explore the political economy of globalization and development. While this literature is evidently eclectic, a common theme that runs across diverse studies is the idea that structural inequities exist where there are sufficient resources available to a population to ensure well-being for all but differences in financial, political, or social power mean that some actors can access those resources, while others cannot. This distinction has been applied to the study of food (in)security, for example, where scholars have recognized that there is sufficient food available to feed populations across the globe (Smith et al. 2000) and yet famine and food insecurity persist in certain regions because financial and/or political constraints mean that there is unequal access to that food (Devereux 
2009; Drèze \& Sen 1989; McDonald 2010, Ch.1). Similar discussions of availability and differential access can be found in studies of inequality in healthcare provision (Forman 2007; Hopkins et al. 2010), environmental security (Brklacich et al. 2010; Mustafa 1998), and other domains of human security. While these studies have developed independently from literature that addresses collective grievances and conflict, it is worth noting that the availability/access approach echoes Gurr's understanding of the origins relative deprivation; specifically, the availability of resources in a given polity will inform actors' expectations of the conditions that they could enjoy, while socio-political structures may mean that some groups are capable of accessing those resources, while others are not -- which is an arrangement that could foster feelings of relative deprivation. ${ }^{1}$

In the empirical discussion that follows, we adopt the availability/access framework and use it as a basis for assessing the impact of global processes of privatization and liberalization on structures of (in)equality in emerging economies. Our starting position is the uncontroversial view that a liberalization of trade is changing -- and expanding -- the range of goods, services, ideas, and social networks that are available in emerging economies, as transnational actors enter new markets and bring new products to those economies. Consequently, we expect that globalization is increasing the availability of resources in emerging economies, and we assume that this is raising local expectations about the quality of goods and services that locals could enjoy (as suggested, we focus on the provision of healthcare and education, in particular). At the same time, we explore the possibility of unequal access to newly-available global goods and services. Knowing that political and economic elites -- by definition -- have significant financial resources, political connections, and information at their disposal (see Khan 2012, 362), they are likely to have privileged access to the globalized services that are becoming available in emerging economies. Non-elites, meanwhile, have fewer resources and are, thus, likely to face barriers to access. Where that is indeed the case, non-elites may come to see that they are increasingly deprived in a globalized world, relative to elites. Such a perception, in turn, would provide a structural basis around which political actors could transform existing elite/non-elite divisions into a reframed cleavage that separates globally-connected cosmopolitans from nationally-inclined communitarians.

\footnotetext{
${ }^{1}$ This argument also echoes claims made by Frances Stewart in her explanation of the development of collective grievances alongside 'horizontal inequalities', which are social structures that provide differential access to political and socio-economic opportunities for members of distinct social groups (Stewart 2002; Stewart 2005).
} 


\section{Empirical Analysis: Concepts and Scope Conditions}

To explore the impact of globalization on availability and access in emerging economies, we now investigate recent trends in the provision of healthcare and education in regions that play host to rapidly growing, and globalizing, economies. The aim of our empirical analysis is not to 'test' a causal claim. Rather, our ambition is more modest. Specifically, we aim to investigate whether it is plausible that processes of globalization might reconfigure structures of availability and access in emerging economies, in ways that could contribute to a realignment of social cleavages.

Our immediate outcomes of interest are the availability of new goods, services, ideas, and social networks within emerging economies, and the distribution of access to any newlyavailable resources. For reasons of feasibility, we focus on availability and access in the healthcare and education sectors, in particular. We explore these areas because they have been highly-exposed to the impact of global liberalization and privatization over the past two decades and, as such, they can be seen as 'critical' cases, which can "yield the most information and have the greatest impact on the development of knowledge" about the topic at hand (Patton in Guetterman 2015, 5). The reason for their particular exposure to globalization is that they relate to basic human welfare and, as such, they have traditionally been under the exclusive control of states, as public and non-excludable goods. However, both healthcare and education have undergone rapid processes of privatization and liberalization over the past decade and this has resulted in a sharp upswing in the provision of those services in emerging economies by private, foreign investors.

In terms of plausible 'causal' influences, we are interested how processes of globalization might shape availability and access. Since 'globalization' can refer to a very large range of social, economic, and regulatory processes (Held \& McGrew 2007; Scholte 2005), we narrow the scope of our analysis to the effects of trade liberalization and global privatization, in particular -- for two reasons. First, on a practical level, this step facilitates empirical analysis because the replacement of local, public services with global, private services produces readily observable trends in the availability of goods and services. Second, while being feasible, a focus on liberalization and privatization also provides a relatively comprehensive indication of the wider range of possible impacts from globalization because economic liberalization, in particular, can be seen as the engine of diverse processes of globalization, including immigration, emigration, cultural diversification, and beyond. 
Our universe of theoretical cases is restricted to 'emerging economies', where that term intuitively refers to countries that are "going through rapid economic growth because of changes in markets, technology, business culture and social practices" (Knowledge@Wharton n.d.). While the 'BRIC' countries (Brazil, Russia, India, China) are commonly put forward as typical examples of emerging economies, we are interested in all countries that have recently experienced rapid growth as a result of their integration into global markets. ${ }^{2}$ We recognize that these states are based in diverse regions, and feature diverse regimes, governments and other socio-political institutions -- which are all factors that could inform the impact of globalization on cleavages. However, we bracket that concern here, since we are interested in how globalization might shape structures of inequality within economies that are increasingly exposed to globalization, as a possible precursor to a reconfiguration of socio-political cleavages. The question of how any observed inequality might then shape political contestation in particular cases would vary across contexts, and could be the focus of onward study.

Taking healthcare and education in turn, we first offer background on how globalization has transformed each sector, focusing specifically on the development of markets for 'medical tourism' and the emergence of globalized universities, respectively. Within each sector, we then look at how globalization is reconfiguring structures of availability and access to goods, services, and ideas. Throughout, we rely on relevant literatures but we recognize that our evidence is necessarily fragmentary and anecdotal on occasion, due to existing data limitations. Thus, our claims should be appropriately qualified.

\section{Globalized Healthcare: Availability and Access}

\section{Background}

The globalization of medical care has fundamentally changed the provision of healthcare services throughout the world. That change has been underwritten by the establishment of international treaties that govern, inter alia, pharmaceutical patenting and pricing, flows of health workers across international borders, and transnational medical research involving human participants (Martin et al. 2016). Such a globalization of healthcare markets and research has, in turn, been matched by an increase in the flow of patients seeking medical care outside their countries of residence (Cohen 2014). This international medical

\footnotetext{
2 A list of countries that host 'emerging and developing economies' is provided by the IMF: http://www.imf.org/external/pubs/ft/weo/2015/01/weodata/groups.htm (Accessed 31 May, 2018)
} 
travel is commonly known as 'medical tourism', and it is defined here as travel across international borders for the purpose of receiving medical treatment that is paid for out of pocket.

Understood this way, the market for medical tourism is not a new phenomenon. Even in the ancient world, privileged individuals would travel abroad for the latest trends and developments in medical care, to access spas or other healing locations, or to visit healers who were said to have special knowledge of the healing arts (Bookman \& Bookman 2007). In more modern times, medical tourism has remained common, as wealthy individuals in less economically developed regions have travelled abroad to access care of a higher quality than that available in their home countries. Until recently, therefore, medical tourism has been an expression of privilege, which has seen those with significant financial and political resources travel to receive treatment in regions that feature the most advanced medical professionals and technologies (Hopkins et al. 2010).

Over the past two decades, however, the market for medical tourism has undergone significant expansion, to increasingly include bi-directional travel for private healthcare. Specifically, in addition to the traditional flow of patients from less to more economically developed countries, patients from developed countries are now also travelling to receive private care in clinics that are based in emerging economies such as India, Thailand, Malaysia, Mexico and beyond (Cohen 2014). This 'reverse tourism' is being aided by the development of new, private healthcare facilities in those countries. While such facilities are typically open to local patients who are able to pay for their services (as discussed below), they actively target international patients. In so doing, private facilities in emerging economies try to compete with healthcare providers in more developed settings by offering lower prices, faster access to care, and/or a wider variety of services -- all while maintaining a quality of care that is similar, or superior, to that which is available in advanced economies.

Several factors have contributed to the expansion of the market for medical tourism in emerging economies. First, neoliberal trade policies, including structural adjustment programs, have led to cuts in public subsidies to medical facilities in some emerging economies and, as a result, public clinics in those countries have felt pressure to accept privately paying patients in order to increase their income. This has triggered the establishment of private clinics that provide services to international patients, alongside paying domestic patients who choose to shun underfunded public facilities (Hopkins et al. 2010). The creation of these facilities has, in 
turn, been aided by international trade agreements such as the General Agreement on Trade in Services (GATS), which explicitly addresses the consumption of health services abroad and foreign investment in health infrastructure. In countries (such as India) that have committed to GATS or similar bilateral agreements, foreign investors are effectively given enhanced access to healthcare markets in emerging economies (Smith et al. 2009), and foreign patients face fewer regulatory barriers to accessing the services provided by those markets.

Second, liberalization and privatization in labor and service provision has increased the supply of high-quality healthcare professionals in emerging economies, and eased the flow of private patients to clinics in those countries. Reduced regulatory barriers to travel and work by medical practitioners, for example, promote models of globalized healthcare in which practitioners can travel to work (full or part-time) in private facilities that operate in emerging economies (Snyder et al. 2015). Consequently, although the 'medical brain drain' of health personnel from developing to advanced economies continues to be a concern for international health equity, we now also see practitioners who are ordinarily based in advanced economies moving to staff private healthcare facilities in emerging economies. Those facilities, in turn, have access to an increasingly large potential client base because reduced regulation and increased competition in air travel has lowered the cost of travel and increased the number of air routes, globally (Turner 2007). Thus, whereas it would previously have been cost prohibitive for middle income medical tourists from North America or Europe to travel to India to receive private healthcare, the relative ease of travel has opened up this market of potential private patients to facilities in Asia.

Third, online communication has facilitated the development of a range of affiliated businesses that have contributed to the growth of a global market in healthcare provision. Primary among these businesses are companies and individuals which provide concierge services that link potential customers with facilities abroad. Acting akin to travel agents, these companies advertise the services of specific facilities and practitioners and then arrange for travel, communication between patients and caregivers, and accommodation at the host site. As these facilitators are often based in the patients' own countries (or culturally and economically familiar sites), they also serve to reassure patients about the safety of medical tourism by communicating their messages in a tone that is especially suited to specific market segments (Snyder et al. 2011). Reassurance also comes through the interventions of international accrediting bodies such as the Joint Commission International (JCI), which inspects private clinics for a fee and, in exchange, allows approved facilities to display the 
JCI's seal of approval. For-profit educational and professional bodies operate in a similar manner, providing training and certification programs that medical tourism facilities and other industry bodies can use to provide markers of presumed quality to customers (Turner 2007).

\section{Availability}

The market for medical tourism is seen to increase the availability of health-related goods and services in emerging economies that host medical tourism facilities through several mechanisms. Above all, there is an increase in international and domestic investment in order to develop new facilities that cater specifically to medical tourists. Existing private facilities may also expand to accommodate patient flows from abroad, and there may be efforts to develop the capacity of existing public facilities in order to provide services to private patients. While this infrastructure is specifically developed to accommodate international patients, it also has the potential to make new care options available to at least some members of the domestic population (Bookman \& Bookman 2007). Either way, growth figures for specific countries and facilities generally paint a very positive picture of sectoral growth in medical tourism, suggesting a robust and positive impact on healthcare availability in emerging economies. However, the accuracy of these numbers has occasionally been questioned and stories of failed medical tourism projects are also common (Lunt \& Carrera 2010).

Beyond expanding healthcare facilities, the introduction of private clinics that cater to global markets is also argued to indirectly contribute to an increase in the availability of high quality medical care by encouraging economic growth in emerging economies. The promise of new sources of foreign direct investment, new jobs in building and running medical tourism facilities, new flows of paying customers who add a vacation to their visit, and tax revenues from private clinics are all touted as key trickle-down benefits. If these economic gains are realized at least in part, the argument goes, then a growth in the tax base can be used to build new health facilities, train health workers, and make a range of new and existing health services more widely available within these communities (Hopkins et al. 2010).

Beyond boosting the availability of healthcare infrastructure, an expansion of the market for medical tourism is seen to increase the availability of advanced knowledge and contemporary medical practices in some emerging economies -- particularly in smaller destination countries. Ordinarily, these countries lack the economic capacity and/or domestic population base to support the import of specialist services and technologies. However, when 
emerging economies host medical tourism facilities, they have reason to invest in high-level technologies (to attract paying international patients). They also have the resources needed to allow for such investment (through income generated by those patients). Once technologies and knowledge are imported, those resources are, in theory, also available to the domestic population (Hopkins et al. 2010). For example, the Cayman Islands has long had limited medical services available locally, including cardiac care, due to its small population. However, the development of 'Health City Cayman Islands' has been accompanied by the introduction of a range of specialist heart surgeries; this would not have taken place -- and is unlikely to be sustained -- without medical tourism (Shah et al. 2014). While this expansion of the availability of advanced medical procedures and technologies is particularly felt in smaller destination countries, a similar expansion of availability can be seen in rural and less wealthy communities in large emerging economies. For example, a concentration of dental practitioners catering to international patients in Los Algodones, Mexico, has vastly expanded the range of services available in that community (Adams et al. 2017).

Since the market for medical tourism contributes to the introduction and retention of high level medical expertise in emerging economies, it also increases the availability of choice over healthcare solutions, particularly in destination states where thin state provision of healthcare has previously ruled out the possibility of choosing between treatments and providers based on considerations of expertise and reputation. This boost in choice comes from the fact that practitioners in emerging economies can develop expertise and reputation in narrow fields of medical specialty, knowing that they will be able to offer their treatments to a potentially large pool of private medical tourists who are willing to travel in search of care. Once provided, those specialist treatments can also be made available to locals in the countries where domestic markets and/or public health systems would not ordinarily sustain or justify such super-specialization. Thus, by way of example, a single orthopaedic surgeon in India became well known in online medical tourism fora for offering a specific form of hip replacement that is rarely offered, even in advanced economies (Cameron et al. 2014). While the surgeon's reputation was partly built through the provision of care to foreign patients, private patients based in India could then seek out the doctor's services and choose between the novel procedure or other approaches.

Finally, medical tourism is seen to increase the availability of high-quality, locallytrained, professionals by stemming -- or even reversing -- the 'brain drain' of medical professionals abroad. In the past, highly-trained health professionals from emerging economies 
would have travelled to regions where national healthcare systems pay more, make better use of their training, and offer stable employment. However, the creation of similar positions in local medical tourism facilities means that healthcare workers now increasingly remain in their home countries and, as such, their skills can be made available to the local population, alongside paying foreign patients (Pocock \& Phua 2011). These retained professionals are sometimes complemented by newly-skilled local healthcare workers, who are taught in education facilities that have been specifically established to train staff for the medical tourism sector (Kanchanachitra et al. 2011; Adams et al. 2017).

\section{Access}

A primary appeal of facilities that cater to medical tourism in emerging economies is that they have a price advantage over the sale of comparable treatments in advanced economies. Thus, although local patients in host countries do typically need to pay to access private facilities, the cost of access is not prohibitive for all locals. Several factors allow for these low prices, including lower costs of living and labour, lower malpractice insurance costs, weaker regulatory burdens, and competition between medical tourism facilities (Connell, 2006). The resulting lower prices are primarily advantageous to international patients, to be sure, but relatively wealthy residents of host states can also afford treatments offered at medical tourism facilities and, thus, gain access to global-standard medical treatments locally (Sen Gupta 2008). That said, this is unlikely to be the case for many, if not most, non-elites in emerging economies. In India, for example, the cost of a ten minute outpatient consultation in a private clinic is the equivalent of 'half or more' of a monthly salary for most locals (Shetty 2010). Consequently, private facilities that cater to medical tourists are effectively out of the reach of much of the local population -- unless subsidies are provided, or there are other 'trickle-down' economic benefits from medical tourism for locals.

To that end, proponents argue that direct interventions and indirect economic benefits associated with medical tourism do facilitate local access to private clinics (see Bookman \& Bookman 2007). On the direct front, countries sometimes develop medical tourism with explicit promises to subsidize access to private clinics and/or cross-subsidize the public health sector. These interventions include: provisions that require medical tourism facilities to set aside beds or other resources for low-income residents; stipulations that private wings in public facilities share resources with the public-facing aspects of those facilities; and regulations that direct some or all new tax receipts from medical tourism to the public health system (Johnston 
et al. 2010). Such programs have been developed in India, through the Apollo Hospital group, and in Thailand through Bumrungrad Hospital, although the efficacy and cost-effectiveness of these efforts has not been assessed (Chen \& Flood 2013). On the indirect front, meanwhile, investment in medical tourism can generate short-term employment for locals through work in the construction of new facilities and long-term employment for industry workers -- both of which increase the earning power of some residents and, thus, their capacity to access private care. New employment opportunities also enhance government tax revenues, and those funds can (theoretically) be channeled into subsidizing access to private facilities and/or improving public healthcare facilities.

Despite the possibility of local access to the private care that comes with medical tourism, critics argue that markets for medical tourism generate at least three sets of externalities that can restrict the capacity of non-elite locals to access quality healthcare (Johnston et al. 2010; Turner 2007). First, medical tourism can lead to a redistribution of resources from the public sector to the private, medical tourism-focused, sector. Such redistribution takes place when health planning authorities in host countries use resources from the public sector to promote the development of medical tourism and, in so doing, prioritize the needs of private international customers over local public patients. For example, the government of Barbados has invested heavily in promoting medical tourism with limited success and at a cost in financial and human resources (Snyder et al. 2013). In other cases, countries such as Cuba have hosted international patient facilities within their public hospitals; while these partnerships are promoted as providing new revenue sources for public facilities, critics are concerned that the agreements crowd out local residents by drawing resources and attention away from the public wings of these facilities (Johnston et al. 2010). Critics also argue that the potential for increased tax revenue through medical tourism is something of a chimera since it is likely to be undercut by the offshoring of industry revenues by foreign owners and the introduction of a variety of tariff and tax breaks for foreign investors (Cohen 2014).

Second, while medical tourism facilities may help to reduce the loss of skilled health workers abroad by offering them employment in the private sector in their home states, these same private sector jobs can lure workers from the public health sector into better paying positions in a private sector that does not serve the wide spectrum of local residents (Pocock \& Phua 2011). This shift of human resources is evidently problematic in terms of equitable access to care as it privileges international patients and those among domestic populations who are able to pay for private care -- at the expense of individuals who are looking to access public 
health services or less expensive private services. More problematically, increased demand in the private sector can kick-start a pattern of internal migration whereby skilled health workers move from less desirable rural placements in the public sector to urban placements, and from there into the private sector. Where this migration occurs, the most vulnerable and underserved populations are likely to see their (often already-limited) access to public care threatened by medical tourism (Snyder et al. 2015).

Third, the provision of private healthcare in countries that host medical tourism facilities will not have positive externalities for public healthcare in states where the provision of newly-available services, technologies, and techniques is driven by the needs of international patients rather than the domestic population. Where that is indeed the case, the needs of the least privileged members of host communities will not be met through the increased availability of private international facilities. After all, these individuals lack access to basic medical services and, as such, they would benefit most from preventative and primary care rather than the kind of technologically sophisticated, specialist care that accompanies medical tourism (Hopkins et al. 2010). For example, the aforementioned dental services that are offered to international patients in Los Algodones, Mexico are seen by local practitioners as inappropriate for the locals, who are often explicitly excluded from accessing these services and, at times, even forbidden from entering spaces targeted at medical tourists (Adams et al. 2017).

In sum, then, emerging trends in medical tourism paint a relatively clear picture in terms of availability, but a mixed view in terms of access. While it seems that globalization and privatization of healthcare through medical tourism is increasing the availability of quality healthcare technologies and expertise in emerging economies, evidence suggests that access to those resources, and quality healthcare more broadly, may be restricted to those who can afford private care -- and that means foreigners and local elites. Going forward, the impact on access will be highly context-sensitive and dependent on the regulatory actions of hosting countries, the patient's home country health system, and the actions of those developing medical tourism facilities. 


\section{Globalized Education: Availability and Access}

\section{Background}

Since the 1990s, globalized education has proliferated in various forms: as franchise programs; online learning and distance education; articulation or pathway programs; transnational partnership programs; study abroad programs; joint universities; and branch campuses (Knight \& McNamara 2016). While the global turn characterizing the provision of these services and practices has affected all kinds of education, processes of globalization have had particular impact on the tertiary education sector, where there has been a fluid movement -- both real and virtual -- of knowledge, curricula, faculty, and students from one country to another. The locus of this mobility has shifted significantly over time: from people (students, faculty, scholars), to programs (twinning, franchise, virtual), to providers (branch campuses) (Knight 2014). International branch campuses (IBCs), which are explored here, therefore represent a decisive stage in the rapid evolution of transnational higher education and, specifically, international program and provider mobility.

While there is no official definition of an IBC, researchers at the Observatory on Borderless Higher Education (OBHE) and the Cross-Border Education Research Team (CBERT) define a branch or 'satellite' campus as a cross-border entity that is owned and operated, at least in part, by a foreign education provider, and which awards degree-level credentials in the name of that provider (C-BERT 2017). ${ }^{3}$ This often involves universities based in advanced economies establishing campuses in regions that host emerging economies. Thus, for example, the University of Nottingham has established IBCs in China and Malaysia, New York University has branch campuses in the United Arab Emirates (UAE) and China, whilst Georgetown, Cornell, and Texas A\&M have all established branches in Qatar. Alongside these established IBCs, more recent cooperative arrangements have seen institutions from emerging economies establish branches in other countries that host emerging economies.

A range of factors has stimulated the development of this increasingly globalized form of higher education. In the first instance, the rise of knowledge-intensive trade and services has prompted greater demand for countries to possess a highly technical and specialized labor force (Tierney \& Lanford 2015). The governments of a number of emerging economies have, therefore, sought to enhance the capacity and quality of tertiary education in order to develop

\footnotetext{
${ }^{3}$ A related arrangement is sometimes known as an 'International Joint University' (IJU). This is an institution that is founded through collaboration between foreign education providers and host country institutions (Knight 2017). We follow common practice by referring to all institutions we cite as IBCs.
} 
the kind of human capital needed to generate growth in an increasingly information-based global economy (Spring 2008). Given that local tertiary education institutions in emerging economies are often underfunded, poorly resourced, and largely disconnected from global research networks, such countries have occasionally sought to supplement state educational facilities with foreign institutions -- in the form of IBCs.

At the same time, processes of economic liberalization in emerging economies have presented a commercial opportunity for education providers in countries such as the US, UK, and Australia to expand and realize investment targets in the face of diminishing state funding and rising administration costs at home (Welch 2011; Wilkins \& Huisman 2012). The capacity to seek that revenue by establishing foreign entities has been facilitated by the introduction of international trade policies that protect and promote education as a tradeable commodity, not least the World Trade Organization's GATS. In particular, Mode Three of the Agreement facilitates the commercial presence of a service provider in the territory of other member states. In practice, this means that educational entrepreneurs and their institutions have enhanced access to the private education markets of other member states (Knight 2002; Altbach 2004; Altbach 2015). By virtue of that access, universities based in advanced economies are able to open up IBCs, which create new streams of revenue in a way that allows them to also advertise their 'global' credentials.

In addition to these factors, the rapid development of IBCs across the globe has been facilitated by the emergence of new, transnational networks of quality assurance and accreditation. An example of this is the Quality Beyond Boundaries Group, which was established in 2014 involving agencies in Europe, Asia, the Middle East, North America and Australia. The Cross-border Quality Assurance Network in Higher Education, meanwhile, was established in China in 2016 as 'a communication and co-operation platform' for inter-agency quality assurance across Asia and Europe (Knight \& McNamara 2016, 39). The establishment of these regulatory authorities, and other similar bodies, signals a move towards greater integration and exchange between education providers in emerging and advanced economies.

\section{Availability}

The proliferation IBCs has increased the supply of higher education goods and services in emerging economies. Indeed, the extent and pace of the global rise of IBCs suggests that these institutions are now playing an increasingly significant role in enhancing the availability 
of tertiary education institutions in emerging economies and, thus, the availability of university places in emerging markets. OBHE identified just 24 IBCs in 2002, 162 in 2009, and 217 in 2014 (Tierney and Langford 2015, 288). According to the latest OBHE report, a further 66 branch campuses had started operating by the end of 2015. Some failures and closures notwithstanding, there are now some 249 IBCs worldwide, up 26\% since the end of 2010 (OBHE 2016). Crucially, this increase has featured a marked rise in the flow of IBCs from 'South-to-South', as countries such as China and India, along with the other BRIC economies, have become increasingly involved in establishing IBCs abroad (Huang 2007; Altbach et al. 2009; Becker 2015; Naidoo 2010; Chee et al. 2016)

Beyond sheer numbers of university places, the presence of IBCs in emerging economies arguably enhances the quality of higher education that is available in systems that otherwise lack the capacity to meet local demand for high-level tertiary education (Lane 2011a). That is, by offering international-standard education locally, IBCs are seen to import quality education to regions that would otherwise have few, or no, institutions offering highlevel academic teaching and research (Altbach \& Knight 2007). For example, IBCs from two Australian universities -- Curtin University and Swinburne University of Technology -- now provide the only private tertiary education in the state of Sarawak in Malaysia, a region where public institutions have struggled to meet demand for tertiary education (Lane 2011b). Since this newly available private instruction is provided by foreign universities, with established pedigrees, offering globally recognized credentials, there is a built-in reputational guarantee of the quality of the education provided. Not only does this directly benefit educational systems and students of those systems, but it promises to enhance the soft power of host states, which may come to be seen as centers of advanced learning (Mok 2011; Shams \& Huisman 2016).

Alongside increasing the quantity and quality of tertiary education in emerging economies, the increased supply of higher education services through IBCs has enhanced the availability of globalized (or, at least, Westernized) forms of knowledge, language, and academic practices in countries with satellite campuses. IBCs, by their very nature, increase exposure to globalized ideas through the intercultural platforms, processes, and practices they facilitate (Altbach et al. 2009). Indeed, it is argued that IBCs have emerged as something of a 'global contact zone' -- a platform for cosmopolitan engagement and the development of (selective) cosmopolitan dispositions and subjectivities (Kadiwal \& Rind 2013).

Until now, the model for that engagement has often been liberal and largely AngloAmerican in form, simply because British, American, and Australian universities have taken 
the lead in establishing branch campuses, and English remains the global lingua franca of academia. Notwithstanding critiques of cultural imperialism, the use of English as the language of instruction means that educational resources, research, and ideas that are not available in vernacular languages are increasingly available to students and academics in states that host IBCs, both through teaching at IBCs themselves and through exchanges with home campuses (see Rostron, 2009). While those exchanges often take students from IBCs to English-speaking countries, education providers based in BRIC countries are becoming increasingly active in establishing their own campuses and exchange programs in developing contexts. And beyond BRIC countries, other emerging economies are also looking to establish themselves as 'education hubs'. On the island of Mauritius, for example, the government is keen to attract Indian universities to cater for the largely Indo-Mauritian population while also seeking to attract international students from nearby African countries (Reisz 2016; Chee et al. 2016). Thus, over time, it seems likely that IBCs will diffuse a more diverse range of knowledge and practices.

\section{Access}

To some extent, local students who would otherwise face financial and/or social barriers in accessing private tertiary level education in emerging economies are able to access the forms of globalized, private education that are made available through the establishment of IBCs.

On the financial front, in particular, IBCs and host state governments take a range of steps to ensure that some local students can access the education provided by IBCs. For example, IBCs sometimes set the costs of enrolment, tuition, and maintenance at branch campuses at levels that are significantly lower than the fees charged at home campuses. This is the case at Nottingham Ningbo, for example, where tuition fees are considerably lower than they would be if accessed at source (Nottingham, 2018a). Local access is further facilitated by the fact that local students can work in the labor market while enrolled on courses of study at IBCs, thereby partially offsetting the (opportunity) costs that are incurred by spending time within formal education (see Jeffrey et al. 2007). IBCs themselves often also make various forms of financial support available to local students. Curtin University in Malaysia, for example, offers local students a range of merit-based, needs-based, and industry-supported scholarships and financial aid packages, some of which are backed by the government of Western Australia, where Curtin is based (Curtin 2018a). Students at IBCs sometimes also receive financial support from the governments of host states that are keen to ensure that their 
own citizens can access the campuses based in their countries. Lane and Kinser argue that this amounts to an 'extraordinary form of privatization', whereby states sponsor access to private tertiary education for local students and, in so doing, complement state institutions in achieving public ends (Lane \& Kinser 2011, 255).

Alongside efforts to reduce financial barriers to private education, some IBCs and host governments take steps to mitigate legal and/or social barriers that otherwise limit local access to higher education in host countries -- particularly education of the standard that leading IBCs provide. Thus, in Malaysia, IBCs have ensured that access to their facilities is open to identity groups that have historically been excluded from public education due to the imposition of ethnic quotas (Lane, 2011b). In Qatar, meanwhile, staff from Georgetown made approximately 30 informational visits to local high schools when the university established its branch campus in Education City, while Texas A\&M established an 'Opportunity Program' that actively encouraged and supported applications from Qataris (Witte, 2010, 5). In a similar vein, the Qatari state established an 'Academic Bridge' program, which was designed to support local students who were preparing to apply to IBCs in the country. The program, which still exists, complements the financial support that the Qatari government offers to all local students who attend IBCs based in Qatar (Pessoa et al., 2014).

Despite efforts to facilitate local access to IBCs, the cost of attending these institutions often remains prohibitive to many locals in host states (Marcus 2011). In Malaysia, the annual fees for branch campus programs in business and engineering constitute between 34\% and 77\% of an average yearly income (Tham, 2011, 14). Given these fee levels, it is unsurprising that more than one third of the student body at the University of Nottingham in Malaysia comes from abroad (Wilkins \& Huisman, 2011, 302). Although IBCs (both in Malaysia and beyond) offer grants, subsidies, and loans to support local students, these scholarships are often academically selective and, as such, likely to be particularly accessible to students from more affluent backgrounds who have been exposed to the kinds of education and assessment methods that are used as bases for awarding scholarships. While it is hard to assess whether this is actually the case, it is clear that students from economically-advantaged backgrounds are highly-represented at some of Malaysia's IBCs (Tham, 2011, 17). The access that comes with this kind of family wealth is then reinforced through admissions policies such as those of Curtin University, which offers the siblings of current students a $10 \%$ discount on first-year course fees (Curtin 2018b). Nottingham Ningbo, meanwhile, offers a similar fee reduction for the children, siblings, and spouses of students -- past and present (Nottingham, 2018b). 
In addition to financial factors that place constraints on the capacity of (non-elite) locals to access IBCs, admissions processes can lend a structural advantage to students who have been exposed to the kinds of globalized language, ideas, and forms of education that characterize IBCs -- and this is likely to be students from affluent or socially-privileged backgrounds. The dominance of English as the language of instruction at IBCs means that proficiency in English is often a direct or indirect criterion for admission. Admissions requirements for Bachelor's degree programs at Monash University in Malaysia, for example, are based on a recognized range of pre-university qualifications and capabilities, often dependent on a sufficient level of English (Monash 2017). And even when qualifications through English are not a formal requirement, the simple fact that much teaching at IBCs is delivered in English means that access is effectively restricted to students who have received high-level foreign language instruction in private high schools or elite state schools (see Pessoa et al., 2014). Students at these kinds of institutions are also more likely to have been exposed to the kinds of global ideas and liberal approaches to education that Anglo-American IBCs tend to offer (Farrugia and Lane 2012, 427-28), and this may boost the willingness of applicants from elite backgrounds to access the newly-available forms of education that IBCs advertise.

In sum, although evidence is currently fragmentary, it seems that the increasing commercialization of higher education, as epitomized by IBCs, is reframing discourse surrounding postsecondary education in emerging economies -- from a discussion of public to private goods. Commercialization is also shifting the discourse that surrounds foreign investment and intervention -- from 'one of aid to one of trade' (Coleman 2003, 355; also Knight 2002). In so doing, the globalization and privatization of tertiary education appears to be increasing the availability of globalized forms of higher education in emerging economies while partially limiting access in favor of those who retain the socio-political and financial means that are needed to maintain its increasing costs (Wilkins 2013).

\section{Conclusion}

We opened this article by noting the recent shift in social and political tectonics in regions of the world that play host to advanced economies, as long-standing cleavages between social classes have partly given way to a new cleavage, in which 'cosmopolitans' who benefit from globalization are set against 'communitarians' who are disconnected from global integration and see few benefits from it. In the discussion that followed, we have tried to consider whether this cleavage may also come to divide social groups in emerging economies 
that are increasingly integrated into global markets. In making that consideration, we started from the assumption that globalization could provide a structural foundation for the development of a cosmopolitan/communitarian cleavage if processes of liberalization and privatization allow new goods, services, and ideas to become available to local populations in emerging economies but societies in those countries are stratified in such a way that only elites can access the new products. To explore whether this scenario might play out, we have looked at how globalization is shaping the availability of healthcare and education in emerging economies, and the capacity of local actors to access globalized services in those domains. Our findings are necessarily qualified because relevant evidence is fragmentary at present. That said, our exploration points to some observable trends.

In terms of availability, it seems that the development of global, private markets is increasing the offering of high-quality healthcare and education in emerging economies. The possibility for profit through the establishment of private institutions that attract fee-paying clients from around the world creates incentives for service providers to bring global-standard technologies, knowledge, and personnel to regions where the public sector is weak and/or local markets are not profitable enough to support large-scale private investment. The very fact that local markets alone cannot sustain global-standard private institutions, however, points to the fact that many local residents of host countries do not have the resources that are needed to access the globalized services that now surround them. Foreigners and local elites, however, do. Thus, at present, there is unequal access to the benefits of globalization. That inequality is allowing local elites to connect to global personnel, ideas, practices, and social networks, while non-elites remain disconnected. Consequently, in the absence of market interventions, we can expect that local elites will become increasingly engaged with global processes (from which they benefit), while non-elites will remain relatively disengaged from global processes (from which they see little or no benefit). Such a structure of inequality between globalized elites and nation-centric non-elites could, if politicized, contribute to the formation of a deprivation-based socio-political cleavage in emerging economies -- one that is structured around the same frames of cosmopolitanism and communitarianism that are increasingly defining political contestation in advanced economies.

Going forward, the question of whether processes of globalization will ultimately bind or divide societies in emerging economies depends, in part, on the degree to which governments and private actors take steps to facilitate non-elite access to newly-available global resources. Our two case studies suggest that steps have already been taken in that 
direction. On the governmental side, host state authorities have provided grants and subsidies that help locals cover the fees charged by private service providers; ensured that foreign providers offer their services to a minimum quota of local residents; and redirected tax revenue from private service providers into the public provision of the same services. On the private side, meanwhile, some global health and education franchises have engaged in outreach programs that are designed to encourage locals to access their services and, particularly in the education sector, they have provided grants that are designed to boost local access. Should such access-facilitation programs continue, then it is possible that processes of globalization will increase economic and social connections across states, without reconfiguring and deepening societal divisions within nation-states. In the absence of efforts to facilitate access, however, it is equally possible that globalization will not only diffuse goods, services, and ideas globally - it may also diffuse the cosmopolitan vs. communitarian cleavage that has already begun to divide societies in advanced economies.

\section{Bibliography}

Adams,K. et al. (2017). "Stay Cool, Sell Stuff Cheap, and Smile": Examining How Reputational Management of Dental Tourism Reinforces Structural Oppression in Los Algodones, Mexico. Social Science \& Medicine 190, 157-64.

Allègre,G. (2017, May 3). Macron vs Le Pen: A Referendum on Globalisation? Retrieved 13 December 2017 from http://blogs.lse.ac.uk/europpblog/2017/05/03/macron-vs-le-pena-referendum-on-globalisation

Altbach,P. (2015). Higher Education and the WTO: Globalization Run Amok. International Higher Education, 23, 2-4.

Altbach,P. (2004). GATS Redux: The WTO and Higher Education Returns to Center Stage. International Higher Education, 37, 5-7.

Altbach,P. \& Knight, J. (2007). The Internationalization of Higher Education: Motivations and Realities. Journal of Studies in International Education, 11(3-4), 290-305.

Altbach,P.G, et al. (2009). Trends in Global Higher Education: Tracking an Academic Revolution (Chestnut Hill: Center for International Higher Education, Boston College).

Becker,R. (2015). International Branch Campuses: New Trends and Directions. International Higher Education, 58, 3-5.

Bookman,M. and Bookman,K. (2007). Medical Tourism in Developing Countries. New York: Palgrave Macmillan. 
Bornschier,S. (2009). Cleavage Politics in Old and New Democracies. Living Reviews in Democracy. Available online: democracy.livingreviews.org (Accessed 22 May, 2018).

Bornschier,S. (2010). The New Cultural Divide and the Two-Dimensional Political Space in Western Europe," West European Politics 33(3), 419-44.

Brklacich,M., et al. (2010). Human Security, Vulnerability, and Global Environmental Change. In Matthew, R. et al. (eds), Global Environmental Change and Human Security. Cambridge, MA: MIT Press.

Cameron,K., et al. (2014). Motivation, Justification, Normalization. Social Science \& Medicine, 106(Supplement C), 93-100.

C-Bert. (2017). Branch Campuses. Retrieved on 16 July 2018 from http://cbert.org/?page_id=34

Chee,C.M., et al. (2016). Country of Origin and Country of Service Delivery Effects in Transnational Higher Education. Journal of Marketing for Higher Education, 26(1), 86-102.

Chen,Y.Y.B., \& Flood,C.M. (2013). Medical Tourism's Impact on Health Care Equity and Access in Low- and Middle-income Countries: Making the Case for Regulation. The Journal of Law, Medicine \& Ethics 41(1), 286-300.

Cohen,I.G. (2014). Patients with Passports: Medical Tourism, Law and Ethics. New York: Oxford University Press.

Coleman,D. (2003). Quality Assurance in Transnational Higher Education. Journal of Studies in International Education, 7(4), 354-378.

Connell,J. (2006). Medical Tourism: Sea, Sun, Sand and...Surgery. Tourism Management, 27(6), 1093-1100.

Crouch,C. (2016, September 23). The Familiar Axes of Politics are Changing, with Momentous Consequences. Retrieved 19 July 2017, from https://www.opendemocracy.net/uk/colin-crouch/familiar-axes-of-politics-arechanging-with-momentous-consequences

Curtin University. (2018a). Domestic Scholarship 2018. Retrieved 13 July 2018, from http://scholarships.curtin.edu.my/wp-content/uploads/sites/291/2018/02/DomesticScholarship-2018-_-ONLINE.pdf

Curtin University. (2018b). Sibling Discounts. Retrieved 13 July 2018, from http://futurestudents.curtin.edu.my/siblingdiscounts/

Dancygier,R.M., \& Walter,S. (2015). Globalization, Labor Market Risks, and Class Cleavages (SSRN Scholarly Paper No. ID 2497406). Rochester, NY: Social Science Research Network.

Devereux,S. (2009). Why Does Famine Persist in Africa? Food Security, 1(1), 25-35. 
Dicken,P. (2003). A New Geo-economy. In D. Held \& A. McGrew (Eds.), The Global Transformations Reader. Cambridge: Polity Press.

Drèze,J., \& Sen,A. (1989). Hunger and Public Action. Oxford: Clarendon Press.

Farrugia,C.A. \& Lane,J.E. (2012) Legitimacy in Cross-Border Education: Identifying Stakeholders of International Branch Campuses. Journal of Studies in International Education, 17(4), 414-32.

Forman,L. (2007). Trade Rules, Intellectual Property, and the Right to Health. Ethics \& International Affairs, 21(3), 337-357.

Goldthorpe,J.H. (2002). Globalisation and Social Class. West European Politics, 25(3), 1-28.

Gonzalez-Vicente,R., \& Carroll,T. (2017). Politics after National Development: Explaining the Populist Rise under Late Capitalism. Globalizations, 14(6), 991-1013.

Gruber,L. (2015). Globalization and Domestic Politics: A Call for Theoretical Reorientation. In Charnoz, O. et al. (eds.), Local Politics, Global Impacts: Steps to a Multidisciplinary Analysis of Scales. Farnham: Ashgate.

Guetterman,T. (2015). Descriptions of Sampling Practices Within Five Approaches to Qualitative Research in Education and the Health Sciences. Forum: Qualitative Social Research 16(2), Article 25.

Gurr,T.R. (1970). Why Men Rebel. Princeton: Princeton University Press.

Gusterson,H. (2017). From Brexit to Trump: Anthropology and the Rise of Nationalist Populism. American Ethnologist, 44(2), 209-214.

Held,D., \& McGrew,A.G. (2007). Globalization/anti-globalization: Beyond the Great Divide. Cambridge: Polity.

Hirst,P., \& Thompson,G. (2002). The Future of Globalization. Cooperation and Conflict, $37(3), 247-265$.

Hobolt,S.B. (2016). The Brexit Vote: a Divided Nation, a Divided Continent. Journal of European Public Policy, 23(9), 1259-1277.

Hopkins L., et al. (2010). Medical Tourism Today: What is the State of Existing Knowledge? Journal of Public Health Policy, 31(2), 185-198.

Huang,F. (2007). Higher Education in the Developing and Emerging Countries: A Focus on Transnational Higher Education in Asia, Journal of Studies in International Education, 11(3), 421-32.

Jeffrey,C. et al. (2007). Degrees without Freedom? Education, Masculinities, and Unemployment in North India. Stanford: Stanford University Press.

Johnston,R., et al. (2010). What is Known about the Effects of Medical Tourism in Destination and Departure Countries? A Scoping Review. International Journal for Equity in Health, 9(24), Online. 
Kadiwal,L., \& Rind,I.A. (2013). 'Selective Cosmopolitans': Tutors' and Students'

Experience of Offshore Higher Education in Dubai. Compare 43(5), 689-711.

Khan,S.R. (2012). The Sociology of Elites. Annual Review of Sociology 38, 361-77.

Kanchanachitra,C., et al. (2011). Human Resources for Health in Southeast Asia: Shortages, Distributional Challenges, and International Trade in Health Services. The Lancet, 377(9767), 769-781.

Knight, J. (2002). Trade in Higher Education Services: The Implications of GATS. OBHE: London.

Knight,J. (2014). Three Generations of Cross-border Higher Education: New Developments, Issues and Challenges. In Streitwieser, B. T. (ed.), Internationalisation of Higher Education and Global Mobility. Didcot, UK: Symposium Books.

Knight,J. (2017). The New Faces of Transnational Higher Education. University World News. Retrieved on 4 December 2017 from http://www.universityworldnews.com/article.php?story=20171024133538586

Knight,J., \& McNamara,J. (2016). Transnational Education: A Classification Framework and Data Collection Guidelines for International Programme and Provider Mobility (IPPM). Retrieved on 13 July 2018, from https://www.britishcouncil.org/sites/default/files/tne_classification_frameworkfinal.pdf

Knowledge@Wharton, High School. (n.d.) Emerging Economy - Definition from KWHS. Retrieved on 28 November 2017 from http://kwhs.wharton.upenn.edu/term/emergingeconomy

Krasner,S.D. (2004). Globalization, Power, and Authority. In Mansfield E.D.\& Sisson R. (eds.), The Evolution of Political Knowledge: Democracy, Autonomy, and Conflict in Comparative and International Politics. Columbus: Ohio State University Press.

Kriesi,H. (1998). The Transformation of Cleavage Politics. European Journal of Political Research 33(2), 165-85.

Kriesi,H. et al. (2006). Globalization and the Transformation of the National Political Space: Six European Countries Compared. European Journal of Political Research 45(6), 921-56.

Kriesi,H. (2010). Restructuration of Partisan Politics and the Emergence of a New Cleavage Based on Values. West European Politics 33(3), 673-85.

Lane,J.E. (2011a). Global Expansion of International Branch Campuses: Managerial and Leadership Challenges. New Directions for Higher Education, 155, 5-17

Lane,J.E. (2011b). Importing Private Higher Education: International Branch Campuses. Journal of Comparative Policy Analysis, 13(4), 367-81. 
Lane,J.E., \& Kinser,K. (2011). Reconsidering Privatization in Cross-Border Engagements: The Sometimes Public Nature of Private Activity. Higher Education Policy, 24(2), 255-73.

Lipset,S., \& Rokkan,S. (1967). Cleavage Structures, Party Systems, and Voter Alignments: An Introduction. In Lipset,S. \& Rokkan,S. (eds.), Party Systems and Voter Alignments: Cross-National Perspectives. New York: Free Press.

Lunt,N., \& Carrera,P. (2010). Medical Tourism: Assessing the Evidence on Treatment Abroad. Maturitas, 66(1), 27-32.

Mair,P. (2012/2006). Cleavages. In Katz,R.S. and W.J.Crotty (eds.), Handbook of Party Politics (London: Sage Publications).

Marcus,J. (2011). 'Cut the Branches, Try a Safer Route'. Times Higher Education Supplement (November 17).

Martin,G., et al. (2016). Globalization and Health: Developing the Journal to Advance the Field. Globalization and Health, 12(6), Online.

Matti,J., \& Zhou,Y. (2017). The Political Economy of Brexit: Explaining the Vote. Applied Economics Letters, 24(16), 1131-34.

McDonald,B. (2010). Food Security. Cambridge: Polity Press.

Mok,K.H. (2011). The Quest for Regional Hub of Education: Growing Heterarchies, Organizational Hybridization, and New Governance in Singapore and Malaysia. Journal of Education Policy, 26(1), 61-81.

Monash University, Malaysia. (2017). Entry Requirements. Retrieved 26 October 2017, from http://www.monash.edu.my/study/entry-requirements

Mustafa,D. (1998). Structural Causes of Vulnerability to Flood Hazard in Pakistan. Economic Geography, 74(3), 289-305.

Naidoo,V. (2010). Transnational Higher Education: Why It Happens and Who Benefits? International Higher Education, 58, 6-7.

[University of] Nottingham. (2018a). Undergraduate Tuition Fees and Finance. Retrieved 13 July 2018, from https://www.nottingham.edu.cn/en/study/undergraduate/tuition-feesfinance.aspx

[University of] Nottingham. (2018b). Scholarships for Degree Programme Applicants. Retrieved 13 July 2018, from https://www.nottingham.edu.cn/en/study/moneymatters/scholarships-for-degree-programme-applicants.aspx

OBHE. (2012). International Branch Campuses: Data and Developments. London: OBHE.

OBHE. (2016). International Branch Campuses: Trends and Developments, 2016. London: OBHE. Presentation by Garret,R., Kinser,K., and Merola,R. Retrieved on 16 July 2018 from http://www.obhe.ac.uk/documents/download?id=1049 
Pessoa,S. et al. (2014). Students' Challenges and Development in the Transition to Academic Writing at an English-medium University in Qatar. International Review of Applied Linguistics in Language Teaching, 52(2), 127-56.

Pettifor,A. (2017). Brexit and its Consequences. Globalizations, 14(1), 127-32.

Pierson,P. (2000). Increasing Returns, Path Dependence, and the Study of Politics. American Political Science Review, 94(2), 251-267.

Pocock,N.S., \& Phua, K. H. (2011). Medical Tourism and Policy Implications for Health Systems: a Conceptual Framework from a Comparative Study of Thailand, Singapore and Malaysia. Globalization and Health, 7(12), Online.

Reisz,M. (2016). Branching Out in Mauritius. Times Higher Education (October 6).

Retrieved on 13 July from https://www.timeshighereducation.com/features/branchingout-in-mauritius

Rodrik,D. (2017). Populism and the Economics of Globalization. Working Paper, Harvard University: Cambridge, MA.

Rostron,M. (2009) Liberal Arts Education in Qatar: Intercultural Perspectives. Intercultural Education, 20(3), 219-29.

Saval,N. (2017, July 14). Globalisation: the Rise and Fall of an Idea that Swept the World. Retrieved 5 October 2017, from https://www.theguardian.com/world/2017/jul/14/globalisation-the-rise-and-fall-of-anidea-that-swept-the-world

Schmidt,V.A. (2017). Britain-out and Trump-in: A Discursive Institutionalist Analysis of the British Referendum on the EU and the US Presidential Election. Review of International Political Economy, 24(2), 248-69.

Scholte,J.A. (2005). Globalization: a Critical Introduction. Basingstoke: Palgrave Macmillan.

Sen Gupta,A. (2008). Medical Tourism in India: Winners and Losers. Indian Journal of Medical Ethics, 5(1), 4-5.

Shah,B.R., et al. (2014). Health City Cayman Islands and the Globalization of Health Services Delivery. American Heart Journal, 167(5), 770-774.

Shams,F., \& Huisman, J. (2016). The Role of Institutional Dual Embeddedness in the Strategic Local Adaptation of International Branch Campuses: Evidence from Malaysia and Singapore. Studies in Higher Education, 41(6), 955-970.

Shetty,P. Medical Tourism Booms in India, but at What Cost? The Lancet, 376(9742), 67172.

Smith,L.C., et al. (2000). The Geography and Causes of Food Insecurity in Developing Countries. Agricultural Economics, 22(2), 199-215.

Smith,R.D., et al. (2009). Trade in Health-related Services. Lancet, 373(9663), 593-601. 
Snyder,J., et al. (2011). The 'Patient's Physician One-step Removed': The Evolving Roles of Medical Tourism Facilitators. Journal of Medical Ethics, 37(9), 530-34.

Snyder,J., et al. (2015). Medical Tourism's Impacts on Health Worker Migration in the Caribbean: Five Examples and their Implications for Global Justice. Global Health Action, 8, 27348.

Snyder, J., et al.. (2013). Understanding the Impacts of Medical Tourism on Health Human Resources in Barbados: a Prospective, Qualitative Study of Stakeholder Perceptions. International Journal for Equity in Health, 12(2), Online.

Spring,J. (2008). Research on Globalization and Education. Review of Educational Research, $78(2), 330-63$.

Stewart,F. (2005). Groups and Capabilities. Journal of Human Development, 6(2), 185-204.

Stewart,F. (2002). Horizontal Inequalities as a Source of Conflict. In Hampson,F.O \& Malone, D.M. (eds.), From Reaction to Conflict Prevention (Boulder/London: Lynne Rienner Publishers).

Tham,S.W. (2011). Exploring Access and Equity in Malaysia's Private Higher Education. ABDI Working Paper Series, no. 280. Tokyo: Asian Development Bank Institute.

Tierney,W.G., \& Lanford,M. (2015). An Investigation of the Impact of International Branch Campuses on Organizational Culture. Higher Education, 70(2), 283-298.

Toly,N. (2017). Brexit, Global Cities, and the Future of World Order. Globalizations, 14(1), $142-49$.

Trubowitz,P. (2016, November 28). Trump's Victory Will Fuel the Growing Backlash against Globalization in the West. Retrieved on 16 July 2018 from http://blogs.lse.ac.uk/usappblog/2016/11/28/trumps-victory-will-fuel-the-growingbacklash-against-globalization-in-the-west/

Turner,L. (2007). 'First World Health Care at Third World Prices': Globalization, Bioethics and Medical Tourism, BioSocieties, 2(3), 303-25.

Welch,A. (2011). Higher Education in Southeast Asia: Blurring Borders, Changing Balance. Abingdon, Oxon: Routledge.

Wheatley,J. (2016). Cleavage Structures and Dimensions of Ideology in English Politics: Evidence From Voting Advice Application Data. Policy \& Internet 8(4), 457-77.

Wilkins,S. (2013). The Future of Transnational Higher Education: What Role for International Branch Campuses? In de Wit,H. (ed.) Possible Futures: The Next 25 Years of the Internationalisation of Higher Education (Amsterdam: European Association for International Education).

Wilkins,S., \& Huisman, J. (2012). The International Branch Campus as Transnational Strategy in Higher Education. Higher Education, 64(5), 627-45. 
Wilkins,S., \& Huisman, J. (2011). Student Recruitment at International Branch Campuses: Can They Compete in the Global Market? Journal of Studies in International Education, 15(3), 299-316.

Witte,S. (2010). Gulf State Branch Campuses: Global Student Recruitment, International Higher Education, 58, 5-6.

Zürn,M. \& de Wilde,P. (2016) Debating Globalization: Cosmopolitanism and Communitarianism as Political Ideologies. Journal of Political Ideologies 21(3), 280301. 